ACTA UNIVERSITATIS LODZIENSIS

FOLIA LITTERARIA POLONICA 7(45) 2017

http://dx.doi.org/10.18778/1505-9057.45.01

Tomasz Bocheński*

\title{
Freedom and secretiveness, in late modernism
}

In contemporary Polish, there often appears the trivial mistake: "in another optics," or, even worse, "to change the optics of seeing." That fallacy sounds like breaking a lens or crushing glasses, yet I wish to make that mistake, I wish to prove another way of seeing. I wrote "seeing", but, in fact, what I meant was "nonseeing", "shutting my eyelids", and "pretend and real blindness." I have already fallen into contradictions, from which no paradox can retrieve me, though I have prepared several paradoxes in my defence. For a second, the glare of a paradox beautifully lights up the darkness. What I mean, though, is darkness viewed in permanent light. Had I started with the following invitation: "I wish to explain the problem of secretiveness in contemporary culture," I would had acted against my internal defiance towards the mechanisms of writing, I would had broken the principle which I wish to present in ill light - the principle of general explaining. Therefore, I shall write about light, explaining, and transparency transitioning freely from metaphor to notions, from a person to a shadow, and from openness to secretiveness. I am actually not driven by an objection to openness, rather by my laughter caused by openness which demands the right to become the whole world. That laughter arrives from a clearly realised darkness. A shadow and secretiveness are two metaphors which I feel as the manifestations of darkness in the life of an individual. The "manifestations of darkness" formula sounds like a quotation from Novalis, or from the gnostic Miłosz, and refers to the currently disdained metaphysics. Surely I will not avoid that label, though I am referring to darkness and lightness tailored by obvious views. I apply the metaphor of darkness to the area unidentified by man: things unidentified in the past, unforeseen in the future, unilluminated in the individual, unread in the cosmos and the cosmic existence of humanity, and unknown within the matter of the cosmos itself - one could list many more dark and black things. However, for me the darkest of all seems not the darkness of the unknown but the time which precedes existence, and occurs afterwards. The flash of existence lights up the darkness of endless time - that is

* Dr hab. prof. UŁ, e-mail: tomasz07@wp.pl, Department of 20 th and $21^{\text {st }}$ century Polish Literature, Faculty of Philology, University of Lodz, 91-404 Lodz, 171/173 Pomorska street. 
one of the maxims that come to my mind. Yet no maxims are needed. It will suffice to compare our persistence and that of a cobblestone, or to slowly descend the tree of evolution to the form of primeval life, or to take up the theories of the beginning of the universe, and experience a work of art. Yes, that will suffice to find measure between darkness and lightness, that will suffice to laugh at the common openness and transparency. But why are openness and transparency so murky?

In the era of revealing and transparency, it is difficult to keep a secret. Mystery became exceptionally valuable and exceptionally cheap. What I mean is the selling price. People value those secrets which can be sold, and devalue others for which the demand is low. It is difficult not to succumb to profit, and sell hidden content. When we consider the significance of a secret traditionally, and when we understand the price literally, we avoid a sale of secrets. Today, it is often the case that secrets once valued extremely high, are incredibly difficult to sell. Not only to sell, but also to share or even reveal. I am referring to artistic and spiritual forms, which also, once revealed, remain impenetrable for some, not secrets of exact sciences, which were valued only once, i.e. at the time of sale. I focus only on the hidden meanings of modernist culture, which, possibly, are also the terminal values of modernism. Let us say that I treat secretiveness as the sign of the end of that trend. I similarly interpret the fact of discounting secrets. In such an intellectual project, it would be difficult not to use notions which present the play between a secret and revealing, as the dialectics of secret knowledge and the knowledge of a blasphemer, esoterica and exoterica, initiation and surface, eliteness and egalitarianism. The lexicon of modernism suggests many terms, which translate into or quote religious terms. Out of that extensive collection, I choose non-obvious terms, though generally understood and used in their metaphorical meanings: secretiveness and shadow. I associate those terms with the understanding of internal freedom. I do not introduce the third value, so obvious in the era of revealing, i.e. "silence", though I shall also discuss silence, which is afraid to or does not want to speak. I am rather interested in the "eloquent silence", or even talkative silence or talking about silence. That paradoxical revealing is interesting not only then when it reveals a secret, but also when it wishes to maintain it, concealed. On which side does the literary scientist who studies secrets stand? On the side of general transparency or on the side of keeping a secret hidden? I believe that the modern researcher gradually transitions to the side of devaluing it. Initially, they introduce readers into the secrets of a work, later once more reveal secrets which had previously been discussed by the writers themselves, and finally begin selling literary meanings as one sells slogans, articles and gossip. I am interested in

${ }^{1}$ T. Merton, Zapiski wspótwinnego widza, trans. Z. Ławrynowicz and M. Maciołek, Dom Wydawniczy Rebis, Poznan 1994, p. 311. [English version: Merton, T. Conjectures of a Guilty Bystander, New York 1966]. 
the reflection from before today's world of common devaluing, or, more precisely, in artistic freedom, not yet screened, not yet sold, but already sensing a common pressure to reveal and sell. I would like to focus on the philosophy of secretiveness, and the methodology of secretiveness, if you will. In the essays of mature modernism, I seek deliberations on the topic of secretive being. What I actually mean is the secret yet without metaphysics; secret, creative and possible independent existence, and such thought. I should also add to that a clear thought on secretiveness. Yes, I seek clear secretiveness in the times of murky transparency.

Humour and irony, so common in modernist literature, deprive a secret of its eschatological meaning focussing on a secret that shall not be revealed by the Supreme Being on the Final Day. Therefore, the shadow comes from the refusal of light, and from a lack of hope for the final healing of the world and man. It is not the cool shade offering respite, but a shadow dragged behind oneself. Saint Thomas Aquinas called that cognitive darkening angustia, i.e. pain and frustration due to an inability to transcend certain limitations. ${ }^{2}$ In short, there is a fundamental difference between the shadow of faith, and the shadow of modern doubt, between a secret in relation to the sensed mystery, and a secret in relation to cosmic solitude. There is also a difference between silence strengthened by faith, and silence triggered by a fear of triviality. However, one needs only to utter the words "triviality" or "profanation", to find a link between the secret of faith, and secretiveness in modernist literature. I can hear that kinship, though unclear, when I read Thomas Merton's remarks on the power of Saint Thomas Aquinas: "There is in St. Thomas more than the dry light of the classroom and the businesslike proving of theses. His understanding, which is clear as day, owes much also to the "night spirit" which communes with what he did not know (...) He is not all talk, not a scholastic machine for grinding out answers. Though he was a prodigious teacher and writer, the force of his words comes from his silence and his respect in the presence of what could never be said." He protected himself against turning into a writing machine for explaining the secrets of the faith, into a scholastic machine. He was also protected by the spirit of the night, dark by definition, known from the writings of Pseudo-Dionysius. But what should we call the modern machine for explaining? And what secrets does a modernist writer want to hide from common transparency?

W.G. Sebald in his deliberations on a play entitled Kaspar by Peter Handke, quickly fell into sarcasm regarding the modern pressure for naming things. He referred to that necessity as the "colonial empire of the spirit." It resembles Musil's ironic comparison of knowledge to parsimony and scrimping, i.e. to "internal

\footnotetext{
${ }^{2}$ Ibid., p. 294.

${ }^{3}$ W.G. Sebald, Campo Santo, trans. M. Łukasiewicz, Wydawnictwo WAB, Warsaw 2014, p. 69. [English version: Sebald W.G. Campo Santo. New York 2005].
} 
capitalism." Kaspar was colonised, enlightened and terrorised, i.e. taught. The educational machine worked on transforming him into a citizen. Apparently Sebald easily turned the meaning of educational work. Kaspar found himself in "new and excessively bright surroundings." He treated explaining and naming as part of himself, as an internalised obtrusive voice, as if it was his "own individual madness." From that conclusion there is but one step to comparing the grammar of an utterance to torture devices, and naming to dissection. Sebald also recalled the well-known concretisation of the dissection machine from In the Penal Colo$n y$ by Franz Kafka. And then he stops us in the reading using an aphorism, which he recorded in an electronic modern style: "But what is taken from the living substance of the individual in the long process of his training to become an articulate, moral human being adheres to the linguistic machine until in the end the parts become interchangeable in function." Isn't that a beautiful and terrifying transformation? A metamorphosis which should be dreaded according to writers from Čapek and Kafka, through Witkacy and Schulz, to Różewicz and Ionesco. Sebald did not emanate fear, but rather a contention of mechanisation, of a common dissection. In his essay, the writer imperceptibly identified with Kaspar, and began to consider himself as a victim of lightness. Only the times changed, and Kafka's machine was perfected. Sebald referenced a statement by Lars Gustafson, who believed that in relation to machines we can comprehend our simulated lives, our lives as linguistic machines. I wrote "our" to avoid the well-known mistake, when a person writing about common decadence herself/himself avoids degeneration. It is, of course, not only about the meeting between a writer and the linguistic machine, but also the linguistic machine within the writer. When Sebald depicted the modern individual, he also depicted himself, at least the unwanted and alien self: "A human being, then, is a Stymphalian creature of metal screws and springs, blanking widespread patterns made of communication sheet metal, and language, apparatus which has gone out of control, and begins to lead a menacing life of its own." In that beautiful description of a mechanised being, what is surprising is the reference to the Hercules myth. Is it possible that people wound up with prattle resembled the Stymphalian birds, which often killed humans and animals with whole clouds of bronze arrows? In the myth, the swamp birds had beaks and wings made of that alloy. Travellers had to protect their bodies under sophisticated armour, since such metal beaks could pierce many metal breastplates. Hercules used some magic rattle to scare away flocks of them and shoot them down. Maybe that is a way to deal with prattle, and mechanical speakers? To use a barrel organ, a voice recorder, or a prayer wheel? In the myth, some Stymphalian beings

\footnotetext{
${ }^{4}$ Ibid.

5 Ibid., p. 71.

${ }^{6}$ Ibid.
} 
escaped alive to multiply elsewhere, and to poison with their faeces other fields away from the swamps. In Sebald's essay, there is no encouragement for heroic deeds. Kaspar submits to lightness, and begins to imagine himself according to the mechanisms of communication, or rather not Kaspar but, as Sebald wrote, Kaspars as the mechanised language produced identities similar to each other. The name Kaspar is given to several "copies". Not everything is entirely proper with those copies or blanks, maybe because education began so late? Maybe that is why Kaspar nostalgically reminisced about times before he spoke a dead language? When his rebellion had not been broken yet? Actually only regression, to use Schulz's term, offers hope for freedom. Kaspar draws from an unclear, unilluminated by the word, uneducated zone, hope for himself, and from that zone Sebald derived free creativity. An experience not yet named using any available and imposing words also reveals the meaning of common openness. Repeated common words are mere "dead abridgement of the whole," as Cassirer stated in the conclusion of the essay. In his final sentence, Sebald inscribed a hope of the time of modernism - on the possibility of saving art: "Literature can transcend this dilemma (of a language as a dead abridgement of existence - TB) only by keeping faith with unsocial, banned language, and by learning to use the opaque images of broken rebellion as a means of communication."

In a book entitled Vie secrète, Pascal Quignard described the mystery of love and desire, and found for his topic analogies which amplified the significance of leaving people and leaving one's time. Many modernist artists sought forms of protecting and creating themselves away from the public pedagogy, forms which would be different from the common formation of individuals. Those private exercises of the spirit were not as threatened as they are today because never before had so many languages illuminated an individual. In an aphorism formed in Nietzsche's style, Quignard offered the following syllogism: "To have a soul means to have a secret. Conclusion. Few people have souls." Nonetheless, it is an enthymeme, while omitting the premise which I would state as follows: most people allow others to browse them, or, slightly differently, in Quignard's manner: few people protect their secrets. That syllogism resonates with sarcasm, visible also in other statements of the writer: "The most contemptible is the man who cannot leave the place of his birth, and cut the strings in which he was entangled in the first years of his life by the fear of obedience: to the family, group, and silent impulses."

Fascination gives way to desideration.

"An aristocrat freezing in front of a portrait of his ancestor. A master chef avoiding hot spices - they are pathetic." ${ }^{8}$ Where did that sarcasm come from?

\footnotetext{
${ }^{7}$ P. Quinard, Życie sekretne, trans. K. Rutkowski, Vesper, Poznan 2006, p. 76. [English version translated from Polish].

${ }^{8}$ Ibid., p. 172.
} 
From the need to break the bonds which are extremely durable? Paedagogia is doing better in the West every day, even Eros has been taught well? In fact, Quignard referred indirectly to Bataille and his concept of eroticism as a zone of creative existence. For Quignard, Eros, asocial at its beginnings, thus becomes in maturity, restoring the individual obscurity, loss, temporariness, and a complicated relationship with matter and mother. The images and premonitions of the French writer, so close to those of Schulz, refer to speaking which ought to be extracted from bodily matter. That voice incessantly deafened by the prattle of the world, and vocalised by the languages of others, wishes to enter the zones which have not yet been displayed or uttered. Behold the spaces of internal freedom, spaces of recognising oneself. No wonder then that Quignard sought the voice and the touch of his mother before she began to speak the pedagogic voice. That journey outside time and society resulted in literature which refers to shadows, not a discourse which is turned by cognition into a bromide, i.e. makes it part of a common useful surveillance. It is widely known that the author of Vie secrète referred to music, a zone in which the culture of the West has always defended itself against obtrusive words: "Good musicians extract sounds from the most ancient quarters of our bodies (from resonators: the abdomen, the uteral cave, the place of previous residence)." It seems that Quignard saw a relationship between the modern explanation and the Christian concept of morality, as if the modern mind illuminating existence constituted a continuation of the zone of the state and science - the Christian concept of sin and salvation. In the history of thought, he found Tertulian with his phrase "you need to hide even in paradise" to conclude "I do not understand why Tertulian's thesis has not found any continuators." A dark issue that there exists a relationship between the concept of divine omnipresence, an enlightenment mind screening everything, and a modern impersonal alliance between the state and global marketing. That is why Quignard referred to Tertulian's abandoned formula to justify his unclear conscience as an individual secretly recognising the creative significance of Eros. His apophthegmatas refer to a secret which carries the burden of the original sin. "In Eden, the first woman could not have existed without a secret," he wrote supporting the concealed not the omnipresent conscience. The screening view dispossesses the subject of his existential being, and offers him defenceless to social play. Fortunately, Quignard did not focus on the monsters of transparency, indifferently archaic or post-modern, but on protecting a secret because the protection of the creative particular one always happens within a particular existence, not within a public debate when many voices and discourses are vocalised. Whatever the situation might be, social voices will still find a path towards our discussion of ourselves. Thus Quignard

\footnotetext{
9 Ibid., p. 68.

10 Ibid., p. 79.
} 
subjected the principle to a spiritual or rather erotic independence: "The secret: escape that which is verbal, what is social. Not to escape that which is sexual, which is mortal." 11

Or maybe that is not a question of freedom but temperament? - I am starting to doubt Quignard's authoritative words. Is it the temperament, the erotic fire that orders the writer to hide from the community? Maybe that was the reason why he spoke in a dark laconic form, and had no patience for a systematic argument? Those doubts were suggested to me by Merton, who considered Tertulian's words from the treatise on patience. Merton valued that treatise since Tertulian was extremely impatient. Therefore, the treatise bears the signs of an overcome force, actually a force not completely overcome in writing. Tertulian's aphorisms are the marks of vehemence turned into stone. Yet the stone is alive. Impatience hidden in a style full of life. Quignard does not believe in the value of metaphysical discipline, or in the value of sharing with others. He is a loner and an individualist, while he could be just a loner. That has been the feature of many modernists - mistrust for the world. Could that mistrust of an individualist stem from distrust in the value of the secrets being revealed? A secret also becomes an individual matter?! Behold a surprising hypothesis: for modernism, a secret is a form of a public confession. A modernist writer at the same time encrypts and decrypts a confiteor as long as they believe in "absolution" through literature. A widespread revealing bestows upon an individual separate existence a mass dimension, and trivialises the value of a literary confession. To protect a secret means to confer with one's own fate, to talk mechanically means to agree to blurring individual features. Thus is the secret, historically limited, individual, virtually intransmittable. The result of the literary discipline of a loner afraid of transparency and devaluation.

The modern story of secret freedom begins with the start of modernity, and defines one of the most important trends in modernism. That beginning was perfectly expressed by the titles of the two parts of Baudelaire's diaries: Dzienniki poufne (Secret Diaries) and Moje serce obnażone (My Heart Laid Bare). And the two trials of Flaubert and Baudelaire for offending public morality, and the pornographic pleasure of a man who denounced both artists - those hidden masturbations of a good Christian. The accuser condemned mysteries - concealed by him and revealed by the writers, because he wanted to express his submission to socially accepted moral norms and state order. Their, the informer's and the writers', secrets differed considerably as the accuser could not imagine the fact that pornography expressed the same affinity to screening everything as the one displayed by a modern state. Literature protects eroticism against the kitsch of pornography, and other usurpations of rationality and politicisation. The word

\footnotetext{
${ }^{11}$ Ibid., p. 80 .
} 
"protects" hides various meanings. I shall reveal two: an artist protects themselves from the common persuasions, protects their secrets to find visions, which for a moment will become the property of the readers experiencing independence during the reading. In French thought, that co-existence of a secret and a vision was presented by Jean-Noël Vuarnet in: Le Philosophe-artiste. In his analysis, Vuarnet referred to "three central figures of modernity", as defined by Nietzsche, i.e.: the prophet, the scholar, and the leader. ${ }^{12}$ As is widely known, those figures, which in contemporary times "show a uniform underneath their shirts", Nietzsche juxtaposed with an artist, i.e. someone who while being occupied with creating new values, does not care about "herd celebrations." Of course he juxtaposed himself, with all his affinities for a uniform, science, and prophecies. Vuarnet described a philosopher who performed exorcisms on himself to extract from within the unwanted forms of modern civilisation. Vaurnet verified the value of the transformation of a philosopher who becomes an artist/philosopher in the times contemporary for us, in the age of technocratic prophecies, and, if you will, in the age of technocratic transparency. He was anxious about the similarity between Nietzsche's artist/philosopher and a "creator/economist/engineer, like Speer or Keynes." 13 Who are those creators? "Those creators made man and ideology as the objects of their treatments and experiments. They do not need paper or ink - the instruments they prefer include information, propaganda, functional archetypes, and stereotypes. Synthesisers and manipulators of ideology, promoters and producers of circumstantial truths, those prophets do not even need to utter their prophecies, they fulfil them. Technocracy does not want ideologists but teachers who could cope without a doctrine, and pose as "objective" sources of all evaluations, treated no longer as evaluations, but only as the consequences of rational management." 14 Nietzsche's paradox consisted of a prophecy which comes true against it, i.e. based on a false prophet, whose rule should not be fulfilled. Vaurnet exposed the paradox of Nietzsche's creation, and of the creations of other creators, one expressed as: "everyone for themselves," which supposes the depriving of the reasons of those who proceed those (creators). In that lesson, one must add the hidden premise, which transforms the creative reading in repeating and stereotypisation. The abandonment of a hidden work on oneself evoked by a reading occurs in the name of common abandonment of work on one's own identity, on the protection of one's own otherness, on developing one's own shadow. A modern reader wishes to browse a book, and transform into a set of bromides prescribed by some commonly known discourse. They similarly cope with their shadow. They screen it with the zeal of a technocrat, a psychologist, a judge,

12 J.-N. Vuarnet, Filozof-artysta, trans. K. Matuszewski, słowo/obraz terytoria, Gdansk 2000, p. 151. [English version translated from Polish].

${ }^{13}$ Ibid., p. 155.

${ }^{14}$ Ibid., pp. 155, 156. 
a moralist, a priest, a teacher, etc. They replace Nietzsche's instruction "be, if you can, the source of your evaluations" 15 with a more convenient formula "let others evaluate themselves, so we can evaluate them." One basic question deserves an answer: what place within the modern technocratic system does an artist/philosopher who avoids ruling occupy? Vuarnet bitterly answered that the system needs such an artist, it needs "thinkers and theoreticians of their own desires" "to make the system if not fully assimilable, then at least possible: rose-coloured."16 The French philosopher's answer belongs to the well-known tradition of understanding modernity, which is close to me as well. Understanding modernism as a trend, which transforms the severely inhabitable reality created by the mind into a place available for living. Vuarnet is bothered by the utilitarian nature of art activity, which nonetheless supports technocratic goals. That is why he concluded his deliberations with an image of liberation: "It remains a dream of one or several utopias, which would place themselves outside the silent cynicism of administrators, and outside the discourse of doubling theoreticians." ${ }^{17}$ Vuarnet experiences strongly the penetration of the hidden separate zone of visions and thought by public conventionalised discourses. He is so much concerned with the use of thought in the inhuman impersonal process, that he finds little joy in cultivating the shadow, secretiveness, and in practising self-recognition. He is anxious when internal freedom becomes part of a publicly practised positive freedom, which could have such a name only in typologies since he understands public freedom as freedom to fulfil goals which deny the rights of an individual who fulfils them. It is actually the seeming fulfilment of goals, or rather fulfilments, by common goals argued and offered by marketing or political persuasions, that transforms political freedom into public captivity, which calls itself fulfilment or success. Therefore, the artist/philosopher is afraid of being used as a means of soothing mental captivity, while his art shall be transformed into a bromide. What bromide? For example, one that screams: "private narrative", "controversial message", "scandalising image", etc. Vuarnet fears a common right to transparency, according to which a deep shadow must become a shadow which is transparent, comprehensible, and useful.

When we illuminate the hidden, we lose a basic part of internal freedom, which stems from the secret. I do not wish to state that freedom and the secret are, essentially, the same, and that anyone who does not explain a secret salvages their freedom. I am only arguing that the creative work on oneself occurs away from the expressed, rhetoricised, discoursified, and anticipated. How much a culture loses when it is screened by an enlightened mind one can feel when one considers

\footnotetext{
15 Ibid., p. 157.

16 Ibid., p. 176.

17 Ibid., p. 177.
} 
the West from the perspective of the culture of the shadow - from the perspective of traditional Japanese culture. In In Praise of Shadows, Tanizaki Junichiro mentioned many pleasures which one loses in the bright light, from the emotion upon seeing rice in a lacquerware bowl, through raindrops one listens to in the toilet, to ghosts which are not transparent. The Japanese writer was terrified by the European seeking of filth, in full light, and the obsession to mark out borders between pure and impure, an obsession which has also been shared by the Japanese. Europeans expelled from their secrets to the streets and the agora remove in public places and discussions any instances of those from their bodies, homes, and minds. As a result they submit to the present and contemporary times, or actually the obsession of the future, which at some point shall screen everything. Junichiro also defined a shadowy perfect place for Europeans: The light from the pale white paper, powerless to dispel the heavy darkness of the alcove, is instead repelled by the darkness, creating a world of confusion where dark and light are indistinguishable. Have not you yourselves sensed a difference in the light that suffuses such a room, a rare tranquillity not found in ordinary light? Have you never felt a sort of fear in the face of the ageless, a fear that in that room you might lose all consciousness of the passage of time, that untold years might pass and upon emerging you should find you had grown old and grey? ${ }^{18}$ The fear of eternity captivates the people of the West so much that they construct their surroundings to be transparent, and devoid of any shadows. They eat that way, they hygienise sex that way, they clean death that way in order to deprive themselves of the right to a mystery. Michel Maffesoli, a French sociologist and anthropologist, saw in those inclinations manifestations of an Apolline spirit, which wanted to bring to Europe boredom, abstraction, and manipulation. Maffesoli argued that the intellectual whole is currently decaying, and we are entering an era of "a brittle community, fragmented society, tribal community turning the sediment of various particular interests new modes of thinking of the attitude to the natural and social world." ${ }^{19}$ That optimist argues that "we stand on the fringe of the shadow, we return to an existential chiaroscuro." ${ }^{20}$ We stopped seeking God, we are stopping seeking secular divinity in the State, the Institution or the Politics, and we are starting to seek divinity within, in the tribal turbulence, or in the rhythm of the world. ${ }^{21}$ That is the attitude Maffesoli wishes to seek also in contemporary

${ }^{18}$ T. Junichiro, Pochwała cienia, trans. H. Lipszyc, in: Estetyka japońska. Antologia, vol. 3: Estetyka życia i piękno umierania, Krystyna Wilkoszewska (ed.), Universitas, Krakow 2005, p. 92. [English version: Junichiro, T., In Praise of Shadows. Leete's Island Books, Inc. Stony Creek 1977].

${ }^{19}$ M. Maffesoli, Rytm życia. Wariacje na temat świata wyobraźni ponowoczesnej, trans. A. Karpowicz, Zakład Wydawniczy „Nomos”, Krakow 2012, p. 103. [English version translated from Polish].

${ }^{20}$ Ibid., p. 102.

${ }^{21}$ Ibid., p. 108. 
science, which sometimes is still cognition striving for total explanation. He thus wrote about science entangled in modern myths: "There exists science without love, for which one does not pay either with one's existence or even pain." Two lines further on he added a few more epithets: "cool, official scientific knowledge, pretentious and vain." 22

The hidden internal freedom, which creates art or science, sucks many terms into the shadow: primitiveness, Dionysiousness, eroticism, precognition, intuition, pre-existence, silence... Thus I listed the names of modern spiritual exercises, modernist practices for deepening the shadow. Sebald escaped from the modern verbal machine into the zone of regression. Vuarnet does not deceive himself in thinking that artistic practices can oppose technocracy. He sees shelter somewhere in the far archipelagos of thought. Quignard focussed on his secret script similar to that of the others hidden in their niches. Maffesoli believes that in public life there exist many new practices which bring us closer to creative existence, on the fringes of the shadow, while Tanizaki felt that European poetics of lightness can deprive him of everything that he considered close and his own. As the bard said in a poem entitled Wędrówka z cieniem:

Thus we console each other

Walking down long streets...

I'm dragging a shadow, the shadow's dragging me,

Puddles glisten underneath our feet. ${ }^{23}$

\section{Bibliography}

Junichiro Tanizaki, Pochwała cienia, in: Estetyka japońska. Antologia, 3: Estetyka życia i piękno umierania, Krystyna Wilkoszewska (ed.), Universitas, Krakow 2005.

Maffesoli Michel, Rytm życia. Wariacje na temat świata wyobraźni ponowoczesnej, trans. Agnieszka Karpowicz, Zakład Wydawniczy „Nomos”, Krakow 2012.

Merton Thomas, Zapiski wspótwinnego widza, Dom Wydawniczy Rebis, Poznan 1994.

Quignard Pascal, Życie sekretne, Vesper, Poznan 2006.

Sebald W.G., Campo Santo, Wydawnictwo WAB, Warsaw 2014.

Vuarnet Jean-Noël, Filozof-artysta, słowo/obraz terytoria, Gdansk 2000.

22 Ibid., p. 106.

${ }^{23}$ J. Kaczmarski, Antologia poezji, Wydawnictwo DEMART, Warsaw 2012, p. 66. [English version translated from Polish]. 


\title{
Tomasz Bocheński
}

\section{Freedom and secretiveness, in late modernism}

\begin{abstract}
(Summary)
The text considers two metaphors describing creative freedom in modern society: secretiveness and shadow. In the shadow, creative individuals protect themselves against the ubiquitous need to explain and screen life. The text proves that contemporary literature (Sebald, Quinard) and essay (Vuarnet, Maffesoli) search inspiration in secretiveness and shadow while at the same time they see a threat to art in the mechanism of explanation.
\end{abstract}

Keywords: secretiveness, shadow, individual freedom, modern literature 